\title{
POÉTICA FEMINISTA E VIOLÊNCIA: UMA LEITURA DO CONTO “ÁGUA”, DE ANA PAULA PACHECO
}

\author{
Heidy Cristina Boaventura Siqueira* \\ Osmar Pereira Oliva**
}

\begin{abstract}
RESUMO: Este artigo objetiva analisar o conto "Água", do livro A casa deles, de Ana Paula Pacheco, no qual a mulher fala sobre si mesma, promove questionamentos sobre sua condição social e denuncia violências praticadas pelo seu companheiro. O processo de memória/invenção é apontado, neste trabalho, como uma categoria metodológica possível de análise. A memória, forjada no imaginário da autora, promove o que é visto como invenção, mas contendo um gesto questionador, subversivo, feminista.
\end{abstract}

PALAVRAS-CHAVE: Ana Paula Pacheco. Poética feminista. Gênero. Violência.

Numa cultura ainda com herança patriarcal, e, portanto, com uma história literária e tradição crítica seculares, canonizada e construída pela ótica predominantemente do masculino, de forma singular, as mulheres têm rompido com o silêncio que lhes foi imposto, e denunciado a dominação sexista, cultural e ideológica a que foram subordinadas. Em nenhuma outra época, debateu-se e produziu-se tanto material científico a respeito das mulheres e sua produção literária, como nas últimas décadas.

Não podendo dissociar-se a arte do contexto social em que foi produzida, a literatura geral e, em particular, a brasileira, negou legitimidade cultural à mulher, enquanto sujeito do discurso até as décadas de 1960 e 1970, época em que o feminismo se consolidou enquanto movimento político. Mesmo reconhecendo o importante caminho aberto por outras mulheres desde o segundo quartel do século XIX, como Nísia Floresta, por exemplo.

O fundamento deste silêncio feminino vem da estética de base europeia que, tradicionalmente, imputou ao homem a capacidade artística de criar. À mulher, coube a acomodação em papéis de subordinação socialmente definidos, tais como gerir o lar, educar os filhos, entre outros. E, caso se aventurasse na escrita, sua produção resultava, do ponto de vista masculino, como literatura menor, sem valor, ou mera cópia, imitação. Rita Terezinha Schmidt, pesquisadora da literatura de autoria feminina, a partir de aportes de teorias feministas e póscoloniais, afirma que:

Excluída da órbita da criação, coube à mulher o papel secundário da reprodução. Essa tradição de criatividade androcêntrica que perpassa nossas histórias literárias assumiu o paradigma masculino da criação e, concomitantemente, a experiência masculina como paradigma da existência humana nos sistemas simbólicos de representação. (SCHMIDT, 1995, p. 184).

\footnotetext{
* Graduada em Direito (2007); Pós-Graduada lato sensu em Direito Processual (2009); Pós-Graduanda stricto sensu - Mestrado em Letras/Estudos Literários pela Universidade Estadual de Montes Claros - UNIMONTES. Advogada. Servidora Pública Efetiva do Município de Montes Claros/MG. E-mail: heidycristina@adv.oabmg.org.br

** Graduado em Letras Português/Francês (1993); Pós-Graduado lato sensu em Língua Portuguesa e Linguística (1995) e em Filosofia, pela Universidade Estadual de Montes Claros - UNIMONTES; Mestre em Literatura Brasileira (1999) e Doutor em Literatura Comparada (2002), ambos pela Universidade Federal de Minas Gerais UFMG; Pós-doutor em Literatura Brasileira (2007), pela Universidade do Estado do Rio de Janeiro - UERJ. Pósdoutor pela Universidade Federal de Minas Gerais - UFMG (2019). Professor na Universidade Estadual de Montes Claros - UNIMONTES. E-mail: osmar.oliva@unimontes.br
}

IPOTESI, JUIZ DE FORA, v.23, n.1, p. 65-76, jan./jun. 2019 
Silenciada, à mulher coube o papel da reprodução genética e, também, artística, uma vez que era analisada pelo arquétipo masculino, como se "copiasse" a produção ficcional já existente. Virgínia Woolf, em A room of one's own, datada de 1929, traduzida para o português em 1985 (Um teto todo seu), observa que até o final do século XIX a mulher não foi estimulada a desenvolver sua capacidade artística criativa. As poucas que ousaram adentrar nesse universo, até então dominantemente masculino, foram duramente ridicularizadas pela sociedade.

Margareth Rago exemplifica esse fato, em seu artigo intitulado "Adeus ao feminismo? Feminismo e (pós)modernidade no Brasil", de forma concordante com Woolf, ressaltando que as mulheres, aderindo ao feminismo, buscaram por visibilidade em todos os espaços da vida social, política e cultural, tornando-se vítimas de "uma construção misógina e estereotipada", que as definiu como "mulheres tristes e infelizes, frustradas em sua incapacidade de conquistar o "sexo forte"” (RAGO, 1995/1996, p. 17).

Nas décadas de 1960 e 1970, o movimento feminista fortaleceu-se e passou, dentre outras temáticas, a desconstruir os mitos da inferioridade natural feminina, a resgatar a história das mulheres, a reivindicar a condição de sujeito de investigação da própria história, além de rever, criticamente, o que os homens sobre elas haviam dito até então (DUARTE, 1988, p. 70). Nesse contexto, o conceito de gênero passou a ser rapidamente disseminado como alternativa de um novo olhar sobre a sociedade, situando as distinções características entre homens e mulheres nas hierarquias sociais. O conceito de gênero, surge, portanto, como possibilidade de desestabilizar o regime de poder socialmente imposto.

Contribuindo com esse debate, Adriana Piscitelli, apesar de não analisar se o conceito de gênero atendeu à expectativa no qual foi concebido, afirma a importância do seu surgimento e o significativo avanço em relação às possibilidades analíticas anteriormente oferecidas pela categoria mulher (PISCITELLI, 2004, p. 43).

Porém, desde o século XIX, a já tão difundida ideia de direitos iguais à cidadania, pautada na igualdade entre os sexos, impulsionou a mobilização feminista. Partindo do pressuposto de que a subordinação feminina não possuía um caráter natural, mas sim, socialmente construído, as feministas passaram a traçar estratégias para problematizar e diminuir a sujeição da mulher. Nas palavras de Piscitelli, "a ideia subjacente é a de que o que é construído, pode ser modificado" (PISCITELLI, 2004, p. 45). Se as diferenças de gênero se estruturaram em bases essencialmente culturais e sociais, não podiam continuar sendo consideradas naturais; podiam e deviam ser revistas e reconstruídas.

Ainda hoje é comum a confusão entre "gênero" e "mulher", ou mesmo a oposição dos "estudos sobre mulher" aos "estudos sobre gênero". Piscitelli explica que tais equívocos são compreensíveis considerando-se que o conceito de gênero se desenvolveu no âmbito dos "estudos sobre mulher" e com eles compartilhou vários pressupostos (PISCITELLI, 2004, p. 49). Embora o termo gênero já fosse utilizado, o seu conceito foi introduzido nos debates sobre as causas da opressão da mulher a partir do ensaio The traffic in women: notes on the "political economy' of Sex ( $O$ tráfico de mulheres: notas sobre a "economia politica” do sexo), de Gayle Rubin, publicado em 1975.

Em seu trabalho, Rubin teoriza acerca do que denominou sistema sexo/gênero, que seria um aparato social sistêmico que torna uma matéria prima (o sexo), acautelado na sua própria natureza, transformando-a em produto (o gênero). Deste modo, apenas o conceito de gênero estaria sujeito às mudanças históricas. Depreende-se, portanto, que a opressão da mulher não é inevitável, mas sim um produto de relações sociais específicas (PISCITELLI, 2004, p. 49-52).

A reelaboração dos pressupostos teóricos e políticos do movimento feminista desencadeou uma revisão do conceito de gênero. Em 1990, com a publicação do livro Problemas de gênero e subversão da identidade, Judith Butler questiona a identidade como

IPOTESI, JUIZ DE FORA, v.23, n.1, p. 65-76, jan./jun. 2019 
fundamento da ação política do feminismo. Para a autora, reafirmar a identidade da mulher como sujeito do feminismo contribuiria para manter a estabilidade das relações hierárquicas socialmente estabelecidas entre o masculino e o feminino (FIRMINO; PORCHAT, 2017).

Segundo Butler, presumir uma identidade feminina excluiria sujeitos que não se enquadram nas normativas de tal categoria. Afinal, definir mulher poder-se-ia incorrer num engessamento identitário, engendrado pelo sistema de poder dominante que o feminismo, desde sua origem, buscou combater. Butler destaca que o determinismo biológico, baseado nas capacidades humanas reguladas pelo sexo, serviu para naturalizar as desigualdades entre homens e mulheres. Ao se naturalizar o poder, tem-se a capacidade de ocultar seus mecanismos de operação, bem como evitar uma contestação de transformação social. Desta forma, a autora entende gênero como uma construção social.

Piscitelli afirma que Butler contribuiu para o surgimento de linhas de pesquisa sobre gênero não centradas nas mulheres, como estudos sobre masculinidade, gays e lésbicas. Entretanto, a referida autora é alvo de críticas por parte da militância feminista, que considera incompatível com o movimento a abordagem de "gênero sem mulheres" (PISCITELLI, 2004, p. 52). A partir do momento em que as mulheres ampliaram sua participação nas artes, e de forma especial na literatura, fez-se necessário constituir teorias capazes de abarcar as transformações ocorridas.

Constância Lima Duarte, em seu ensaio intitulado "Literatura feminina e crítica literária", destaca o trabalho de Patricia Spacks no sentido de dar destaque à capacidade feminina de, utilizando-se de sua criatividade, combater, ainda que de forma velada, dificuldades específicas. A pesquisadora ressalta os escritos teóricos de Jacques Derrida e Julia Kristeva, para os quais o feminino, considerado como a negação do fálico, poderá desmontar o pensamento falocêntrico ocidental (DUARTE, 1988, p. 72).

Segundo Duarte, no campo da literatura, a questão mais debatida continua sendo a existência ou não de uma literatura especificamente feminina. Apesar de muito ter-se caminhado no sentido de identificar traços distintivos do comportamento e da natureza feminina, para a autora, a linguagem literária feminina parece estar longe de ser definida. Assim, desde Virgínia Woolf até as tendências mais contemporâneas, várias são as tentativas para explicar o que poderia ser chamado "escritura" de mulher:

\footnotetext{
Annie Leclerc e Hélène Cixous exploram a introdução do corpo na arte, a partir de um ângulo distintivo. Para Cixous a escritura feminina significa "escrever o corpo", pois para ela o corpo feminino apresenta "impulsos distintivos e um desejo que surge do inconsciente", para Leclerc "uma linguagem uterina". Kristeva avança um pouco e considera o corpo como "gozo" e como "força semiótica na escritura capaz de quebrar a ordem simbólica restritiva", já Luce Irigaray com o pressuposto de que o "feminino" significa mais que "mulher", procura-o através dos discursos filosófico e psicanalítico. (DUARTE, 1988, p. 73).
}

As teorias mencionadas demonstram que não há entendimento unânime. E nem poderia haver em se tratando de mulheres, seres marcados pela sororidade, mas de características singulares, mesmo quando analisadas no mesmo contexto histórico e cultural. O que se pode referir é que há uma vertente francesa, de natureza psicanalítica e semiótica, a qual investiga os textos de autoria feminina a partir da linguagem, escrita ou simbólica; e uma vertente norte americana, de cunho mais sociológica, a qual prestigia o sujeito que se encontra por trás da escrita, o contexto de produção da literatura e as relações de gênero, que abarcam não apenas o masculino e o feminino, mas também outras categorias, como raça, etnia e classe.

IPOTESI, JUIZ DE FORA, v.23, n.1, p. 65-76, jan./jun. 2019 
Ciente desta singularidade, Lúcia Helena Vianna, em seu trabalho "Poética feminista poética da memória", ressaltando as dificuldades encontradas pelos pesquisadores do feminismo com a literatura de mulheres brasileiras, aponta a memória como uma categoria metodológica na construção de uma poética feminista, tendo como recorte os contos de escritoras brasileiras do século XX (VIANNA, 2003, p. 1). A seleção do século XX, como já mencionado anteriormente, se dá em razão da consolidação do feminismo enquanto movimento político a partir de 1970, o que deflagrou um processo de afirmação identitária, que tem a linguagem como um dos seus espaços de embate.

Por meio da linguagem literária, a mulher fala sobre si mesma e constrói sua subjetividade, questiona as relações sociais, reivindica participação ativa em todos os âmbitos, denuncia opressão e violência, além de dizer seus anseios e desejos. Para tanto, lança mão das memórias, sem deixar de absorvê-las, filtrá-las, transformá-las em ficção.

Para Vianna, poética feminista seria todo discurso produzido pelo sujeito feminino que, assumidamente, ou não, contribua para o desenvolvimento da consciência feminista dando destaque ao papel afirmativo do feminino no mundo público, alterando a ordem vigente estabelecida. Observe-se que o conceito não se refere somente ao modo de escrever propriamente feminino, denominado de "escritura feminina" 1 . Deste modo, destaca ainda a referida autora: "Poética feminista é poética empenhada, é discurso interessado. É política". (VIANNA, 2003, p. 1-2). Ainda segundo Vianna, o conto, por suas características próprias, favorece o processo de memória/invenção. A memória, nem sempre evocada voluntariamente, nem sempre explicitada, às vezes individual, outras vezes coletiva, forjada no imaginário da autora, promove o que é visto como invenção, carregada de extratos pessoais, sociais e culturais, uma narrativa inquietante, subversiva, denunciadora (VIANNA, 2003, p. 1-3).

No mesmo sentido, Benjamin Abdala Júnior reforça as significações que são transportadas ao texto em decorrência da vivência sociocultural do seu denunciante, ainda que de forma inconsciente:

A codificação literária, ao tornar o sujeito da enunciação uma espécie de "radar"
sociocultural, leva-o a trabalhar uma matéria que vai muito além de sua consciência.
Caso ele seja um escritor consciente de seu ofício - como acontece com frequência
entre os escritores de ênfase social -, ele conhecerá a relatividade de suas "estratégias"
discursivas e também as potencialidades das estruturas textuais como elementos
geradores de significação. (ABDALA JÚNIOR, 2007, p. 65).

O texto é fruto do imaginário. Mas este, por sua vez, é uma amálgama de memórias e experiências pessoais e coletivas. Deste modo, o texto literário pode ser interpretado como representação mimética e artística da sociedade e da sua cultura. É nesse contexto que a ficção de mulheres realiza uma denúncia social na profundidade, evocando memórias coletivas, clamando pela conscientização feminina; ainda que de forma suave, sem exageros, sem rebuscamentos. É nesse âmbito, ainda, que se situa o livro da paulistana Ana Paula Pacheco, $A$ casa deles.

Todavia, antes que se proceda à análise proposta como objetivo deste trabalho, faz-se necessário um adendo acerca das características específicas do conto, como anteriormente prenunciado. Antonio Carlos Hohlfeldt, em seu livro Conto brasileiro contemporâneo, ressalta como características do conto: a forma oral como gênese; o "espaço restrito" e o curto lapso de tempo da narrativa, e a escassez de personagens (HOHLFELDT, 1988, p. 12-22). O referido

\footnotetext{
${ }^{1}$ É cabível, nesse contexto, diferenciar feminismo (movimento político-ideológico) de feminino (comportamento da mulher, forma como expressa sua identidade no dia-a-dia).
}

IPOTESI, JUIZ DE FORA, v.23, n.1, p. 65-76, jan./jun. 2019 
autor registra ainda o posicionamento de Câmara Cascudo, para o qual: "o conto popular revela informação histórica, etnográfica, sociológica, jurídica, social. É um documento vivo, denunciando costumes, ideias, mentalidades, decisões e julgamentos" (HOHLFELDT, 1988, p. 14).

Ricardo Piglia, aprofundando nos estudos sobre o assunto, afirma que, se o conto clássico teorizado por Edgar Allan Poe contava uma história anunciando que havia outra, no conto moderno, contam-se duas histórias como se fossem uma só. "O mais importante nunca se conta. A história é construída com o não-dito, com o subentendido e a alusão" (PIGLIA, 2004, p. 91-92). Dessa forma, as características próprias do conto ressaltadas por Hohlfeldt, de forma peculiar, a oralidade, permite uma difusão de ideias, e as propriedades estruturais de economia textual, demonstram-se propícias para o desencadeamento do processo de memória/invenção, teorizado por Vianna.

A coletânea de contos A casa deles foi publicada em 2009, pela editora Nankin, marcando a estreia na ficção de Pacheco, também autora do ensaio Lugar do mito, sobre Guimarães Rosa. Os vinte e dois contos que compõem o livro são, em geral, breves, de frases curtas, ordem direta, narrados em primeira pessoa. Vilma Arêas, no posfácio desse livro, sintetiza os temas tratados na referida coletânea:

\footnotetext{
Os temas de A casa deles giram entre vida familiar e vida na cidade, com suas leis e instituições examinadas em seu momento de quase dissolução. Seu ponto inflamado é o esvaziamento dos personagens, seja pela loucura, que surge normalizada em muitos textos (cf. "Centro), seja pelo controle de alguém que se fez mais forte, como em "Supergato" (humildes tiranizados por outro humilde que sobe na escala), seja ainda de forma mais geral no enquadramento da época da ditadura militar no Brasil, como em “A 20.000 pés”. (In: PACHECO, 2009, p. 90).
}

Nenhum dos contos que compõem a coletânea tem o mesmo título do livro, apesar do trabalho como um todo fazer denúncia social por meio de personagens em espaços de exclusão, sejam moradores de rua, empregadas abandonadas, quando não podem mais servir aos interesses capitalistas, sejam hóspedes de asilos e sanatórios, mulheres que são expulsas da própria casa, dentre outros.

O livro de Pacheco tem por epígrafe trecho extraído de Franz Kafka, A construção: "Aqui não importa que se esteja na própria casa, pois o fato é que se está na casa deles". Assim, o título e a epígrafe do livro, o primeiro inspirado e segundo extraído do fragmento de Kafka, já prenunciam a ausência de domínio do enunciante, o pertencimento a outrem. Ou, pelo viés da ironia, convoca-se o leitor a questionar onde está a voz feminina que tenta se inscrever na ordem do discurso, lugar de fala e de poder tradicionalmente masculino.

Em A construção, a criatura-narradora de Kafka vive sob a terra em túneis e esconderijos por ela escavados. Os referidos túneis guardam a dupla finalidade de habitação e proteção do seu morador. Entretanto, este, de forma paranoica, não consegue viver em paz. Sempre atormentada com invasores, desmoronamentos, e ataques súbitos, a criatura está constantemente escavando, planejando, desenvolvendo estratégias, alargando ou estreitando galerias.

Acir Dias da Silva, em seu artigo intitulado "Imagens de Kafka: olhares para $A$ construção", ressalta que o narrador kafkiano, tomado pela insegurança quanto ao seu destino e totalmente aterrorizado, busca se proteger de inimigos que não são materializados na narrativa, apenas pressentidos por rumores e movimentos generalizados. Entretanto, a vida agonizada por culpas, medos e solidão, desencadeia a própria segregação corporal. (SILVA, 2010).

IPOTESI, JUIZ DE FORA, v.23, n.1, p. 65-76, jan./jun. 2019 
Não por acaso, o primeiro conto do livro de Pacheco, "Água”, guarda relação estreita com a narrativa kafkiana. O referido conto descreve, de forma concisa, mas veemente, a destruição de uma família pelos atos truculentos de um homem. O título remete ao "afogamento" da vida doméstica.

A narradora destaca a capacidade do seu companheiro em destruir tudo o que foi edificado pela família com a força da água. Segundo o Dicionário de Símbolos, de Jean Chevalier e Alain Gheerbrant, a água é tanto fonte de vida como fonte de morte, simbolizando, portanto, a criação e a destruição (CHEVALIER; GHEERBRANT, 1997, p. 16). No conto de Pacheco, a água, que "tudo afundou", é nascente de destruição. Simboliza a ruína do patrimônio em comum, mas também dos bens de propriedade apenas da narradora, possivelmente presentes de parentes próximos ou objetos de herança:

Ele encheu a nossa casa de água. Tudo o que ele pôs ali dentro a água levou. O que ele fez de bom, fez pior logo depois. Mas foi ele quem afundou tudo, cômodo por cômodo, coisa por coisa - as dos meninos dele, as dos meus pais, o sofá da minha avó, a gaiolinha, a gaiolinha da calopsita da menina. Aquilo durou horas e quando ele já estava bem longe, a casa seca parecia o que o mar engoliu e devolveu. (PACHECO, 2009, p. 11).

A água é elemento essencial e imprescindível a um lar, mas em excesso é prejudicial. Assim, o masculino poderia ser considerado relevante na família, mas de forma equilibrada, harmônica. Nesse texto, a voz feminina denuncia a impostura do outro, que não tem limites em sua atuação veemente. Preenche todos os espaços e menospreza os pertences, as pequenas coisas dos que estão em sua companhia. A imagem da casa engolida e devolvida pelo mar intensifica a tragédia familiar. $\mathrm{O}$ homem e o mar se assemelham na figuração do gigante ameaçador, o monstro de boca aberta sempre pronto em sua ânsia devastadora. À mulher não resta alternativa senão o silêncio, o pranto desolado, os restos da destruição.

A água marca ainda o fim das promessas feitas com o casamento e constituição de uma família: "Cumpriu ao contrário o que prometeu, do jeitinho que prometeu, mas ao contrário" (PACHECO, 2009, p. 11). Nesse ritual, o homem promete ser fiel a sua esposa até que a morte os separe; promete ainda cuidar dela na saúde ou na doença, na abundância ou na pobreza. No entanto, essas promessas não passam de um discurso ensaiado e decorado, sem preocupação na vida prática.

A destruição causada pelo personagem masculino também é direcionada aos filhos. De forma figurada, a narradora expressa: "As luzes todas que acendeu, apagou. Até a do quarto dos meninos dele" (PACHECO, 2009, p. 11). O particular também é político. A voz narrativa denuncia a violência doméstica como uma ruptura não só afetiva, mas também social; todos são afetados de forma dolorosa por essa quebra de expectativas da felicidade. O potencial provedor e protetor do lar se torna seu algoz, seu temível e terrível monstro.

Ao fazer uso da expressão "meninos dele", a narradora-personagem de "Água", demonstra, absorta pela violência do companheiro, a ideia de perda do poder familiar sobre os próprios filhos. De forma similar ao narrador kafkiano, a narradora de Pacheco também passa a temer ruídos e sinais do "inimigo": "[...] mesmo na sua ausência, o lugar ainda muda. A cada dia um novo sinal de água aparece. Mofo, relento, um pedaço de tábua, um chiado" (PACHECO, 2009, p. 11-12).

Entretanto, diferentemente do narrador d'A construção, que não faz distinção entre casa, esconderijo e lar por ser um animal, a narradora do conto "Água" demonstra sofrimento com o desmantelamento de sua família, com a destruição do seu lar. Assim, faz referência à sua casa, antes de a mesma ser destruída pelo companheiro, como ninho, lugar que abriga, acolhe,

IPOTESI, JUIZ DE FORA, v.23, n.1, p. 65-76, jan./jun. 2019 
protege: "Tínhamos a vantagem do agasalho, uma casa como um ninho nesta cidade dura. Se quem passasse tivesse a perspectiva de um pássaro grande, concordaria em dizer que a nossa casa era um ninho escondido no cimento" (PACHECO, 2009, p. 12).

Assim como em A construção, a narradora de "Água" também vive em total agonia, buscando defesas na sua própria casa, na qual se enclausura, temendo as ameaças do "inimigo": "Então tranquei a porta e não abri para ninguém" (PACHECO, 2009, p. 12). Ainda se recuperando do "afogamento", a narradora-personagem é surpreendida com a venda da sua casa. Sem que lhe seja dado conhecimento dos compromissos, ou até mesmo a falta deles, que motivaram esta transação entre os compradores e seu companheiro, ela é expulsa de sua morada, juntamente com os filhos. Resta caracterizado o abandono patrimonial e afetivo da família por parte do personagem masculino.

Como se vê, novamente o privado se torna público, pois o conflito pessoal acarreta uma desordem pública de caráter humanístico, pela falta de moradia e acesso aos meios de subsistência. Quando se acaba um casamento de forma violenta, abre-se uma brecha nas bases da sociedade - mais um problema que deve ser de responsabilidade social e ampla, pois dignidade é direito constitucionalmente garantido a todo ser humano.

Inicia-se o "o segundo afogamento, este no seco" (PACHECO, 2009, p.). Da mesma forma que a água, a terra também pode ser interpretada no conto como fonte de destruição, por ser aquela que precisa dos mortos para alimentar-se, segundo Gheerbrant et Chevalier (1997, p. 879). Retomando a teoria de Piglia, percebe-se que o conto ora sob análise narra em primeiro plano a história de um "afogamento" e, em segundo plano, denuncia de forma subjacente a violência doméstica e familiar contra a mulher, hoje tipificada como crime pela Lei $\mathrm{n}^{\circ}$. 11.340/2006, popularmente conhecida como "Lei Maria da Penha".

A "Lei Maria da Penha", considerada uma das mais modernas leis do mundo acerca do assunto, e demonstra a amplitude de sua aplicabilidade, a partir dos vocábulos adotados: violência doméstica, violência intrafamiliar, violência contra a mulher e violência de gênero; cada um desses termos está relacionado a perspectivas de análise diferentes, no que tange ao termo violência e ao predicado que o acompanha. Segundo o artigo $7^{\circ}$ da referida Lei, são formas de violência doméstica e familiar contra a mulher, dentre outras: a física, a psicológica, a sexual, a patrimonial e a moral. A violência física é compreendida como "qualquer conduta que ofenda a integridade ou saúde corporal da mulher".

A violência psicológica é tipificada pela legislação em comento como qualquer conduta que cause dano emocional e diminuição da autoestima da mulher; prejudique e perturbe o seu pleno desenvolvimento ou que vise degradar ou controlar suas ações, comportamentos, crenças e decisões, mediante ameaça, constrangimento, humilhação, manipulação, isolamento, vigilância constante, perseguição contumaz, insulto, chantagem, ridicularização, exploração e limitação do direito de ir e vir; ou qualquer outro meio que lhe cause prejuízo à saúde psicológica e à autodeterminação.

A violência sexual é entendida como qualquer conduta que constranja a mulher a presenciar, a manter ou a participar de relação sexual não desejada; que a induza a comercializar ou a utilizar, de qualquer modo, a sua sexualidade; que a impeça de usar qualquer método contraceptivo ou que a force ao matrimônio, à gravidez, ao aborto ou à prostituição; ou que limite ou anule o exercício de seus direitos sexuais e reprodutivos.

A violência patrimonial é percebida como qualquer conduta que configure retenção, subtração, destruição parcial ou total de seus objetos, instrumentos de trabalho, documentos pessoais, bens, valores e direitos ou recursos econômicos. E, por fim, a violência moral, entendida como qualquer conduta que configure calúnia, difamação ou injúria.

IPOTESI, JUIZ DE FORA, v.23, n.1, p. 65-76, jan./jun. 2019 
Marilena Chaui, em seu livro Sobre a violência, afirma que, etimologicamente, o vocábulo "violência" vem do latim vis, força, e significa:

1. tudo o que age usando a força para ir contra a natureza de algum ser (é desnaturar); 2. todo ato de força contra a espontaneidade, a vontade e a liberdade de alguém (é coagir, constranger, torturar, brutalizar); [...]; 5. consequentemente, violência é um ato de brutalidade, sevícia e abuso físico e/ou psíquico contra alguém e caracteriza relações intersubjetivas e sociais definidas pela opressão e pela intimidação, pelo medo e pelo terror. A violência é a presença da ferocidade nas relações com o outro enquanto outro ou por ser um outro [...]. (CHAUI, 2017, p. 46, grifos da autora).

A construção do conto de Pacheco traz a lúmen uma lamentável face da sociedade brasileira, marcada por atos de brutalidade e abuso físico e/ou psíquico contra a mulher, caracterizada por relações intersubjetivas e sociais definidas pela opressão, pela intimidação e pelo medo. Em "Água", não é possível inferir apenas a presença da violência sexual. Há violência física implícita: "Ele lacrou tudo: os vãos, as saídas, tapou a minha boca e as dos meninos dele [...]" (PACHECO, 2009, p. 11). A violência patrimonial também está registrada no conto de Pacheco, quando a narradora é privada de sua morada, sem qualquer contraprestação financeira, e ainda presencia a destruição de seus bens:

À tardinha outro homem, não o das placas nem o interessado, me avisou que tinha
sido vendida e que ele, o pai dos meninos, o artista ao contrário, tinha deixado um
bilhete para mim. Eu precisava retirar as coisas se quisesse salvar o que é meu. As
minhas coisas, as dos meninos dele, as coisas dele também. Foi quando tudo começou,
o segundo afogamento, este no seco. Dali a dois dias passaram a aterrar. Tijolos,
louças, cimento, ladrilho, tudo servia para dar solidez àquela boca aberta. Os vãos eles
cobriam com muita terra, e a nossa casa destruída eram os dentes, já sem raiz.
(PACHECO, 2009, p. 13).

Já a violência moral manifesta-se sob a tipificação do crime de injúria, prevista no artigo 140 do Código Penal Brasileiro. Para configuração desse tipo penal, é necessário que se deprecie alguém de forma genérica, afetando sua dignidade, sua honra subjetiva. Injúria envolve, portanto, valores sociais e pessoais, e atinge sentimentos de decoro e respeitabilidade. A característica deste tipo penal é a exteriorização do desprezo e desrespeito pela atribuição a outrem de vícios ou defeitos morais, intelectuais ou físicos. No conto "Água”, a injúria está sutilmente configurada quando o personagem masculino atribui à narradora-personagem a característica de gorda, com desdém: "Me chamou de pesada" (PACHECO, 2009, p. 11).

Entretanto, o que sobressai no texto é a intimidação da narradora pelo seu companheiro por meio da violência psicológica. Em vários trechos, a narradora explicita, de forma veemente, o seu medo:

\footnotetext{
Não gosto quando me olha e sorri, desconfio dele mesmo na lembrança. (PACHECO, 2009, p. 11).

A cada dia um novo sinal de água aparece. Mofo, relento, um pedaço de tábua, um chiado. Mas considere, ele disse. Você está deixando de considerar que estou aqui hoje (ele disse depois). (PACHECO, 2009, p. 12).

Você está deixando de considerar que estou aqui hoje (ele disse) e que me apego aos que machuco. (PACHECO, 2009, p. 12).
}

As marcas da dominação e da violência masculinas se ampliam do físico ao psicológico. Mesmo na ausência, a mulher sofre com as lembranças do homem com quem conviveu. E se desvela, ainda, a mais inesperada declaração: apegar-se a quem se machuca. A delimitação do

IPOTESI, JUIZ DE FORA, v.23, n.1, p. 65-76, jan./jun. 2019 
território é configurada pela fala reiterada do homem, ao lembrar à companheira, diversas vezes, que ele está na casa, como uma ameaça de poder opressor e de violência anunciada.

Fazendo uso dos termos de Piglia, a "verdade secreta" revelada na "superfície" (PIGLIA, 2004, p. 94), no conto “Água”, é a evocação de memórias da coletividade de mulheres que são assim constrangidas, cotidianamente, das mais diversas e brutais maneiras possíveis, pelo fato de serem mulheres numa sociedade de herança patriarcal e autoritária. Nessa narrativa, nenhum personagem é nominado, o que remete à ideia de que pode ser qualquer um em situação idêntica. Ou, ainda, que o relato feminino traz a história de um coletivo de mulheres, em contextos de vida diferentes, mas submetidas à mesma violência.

Em relação aos diversos tipos de violência, a filósofa Marilena Chauí afirma que esta é legitimada na sociedade brasileira hodierna porque o meio social ainda conserva as marcas da sociedade colonial escravista, assinalada pelo predomínio do espaço privado sobre o público e centralizada na hierarquia familiar patriarcal. Para ela, a sociedade brasileira é fortemente hierarquizada em todos os seus aspectos. Assim, repetindo a forma da família patriarcal, "as relações sociais e intersubjetivas são sempre realizadas como relação entre um superior, que manda, e um inferior, que obedece". As diferenças sociais reforçam a de "mando-obediência", de modo que "o outro" jamais é reconhecido como sujeito de direito. A referida autora adverte, todavia, que, "quando a desigualdade é muito marcada, assume a forma da opressão" (CHAUI, 2017, p. 58-59).

Desse modo, apagada a alteridade, há o encolhimento do espaço público (da lei e dos direitos) e o alargamento do espaço privado (da vontade arbitrária); o que a filósofa denomina de "autoritarismo social" (CHAUI, 2017, p. 60). Neste contexto, a mulher, vista na sociedade de herança patriarcal como inferior em decorrência da suposta natureza de fragilidade, tem sua desigualdade fortemente marcada em relação ao sexo masculino. Essa desigualdade assume a forma de opressão. A mulher, portanto, em posição de inferioridade na sociedade hierarquizada, passa a ser silenciada e subjugada pelo homem.

A violência está de tal modo interiorizada na sociedade que a desigualdade salarial entre homens e mulheres que realizam atividades idênticas, por exemplo, é considerada normal; e a violência é tida como inexistente. Desse modo, ainda de acordo com os estudos de Chauí, em decorrência do mito da não violência, mantém-se à sombra o fato que a sociedade brasileira ainda hoje é verticalizada, hierarquizada, autoritária e por isso mesmo violenta.

O conto "Água" busca trazer luz a essa sombra. É um convite à reflexão, mas, também, a uma tomada de consciência, e, sobretudo, mudança de atitude. A escrita de Pacheco, ainda que fazendo uso de "arma branca", nas palavras de Vilma Arêas, é denunciadora e engajada, reflexo de uma memória coletiva feminista, evocada para, de forma específica, recordar que, não obstante as conquistas sociais alcançadas, muitas mulheres (não importa que estejam na própria casa) ainda continuarão "na casa deles", dos homens truculentos, por não saberem/poderem impor a sua vontade.

Constata-se, portanto, que a literatura de Pacheco pode ser analisada sob a categoria metodológica da memória, conforme elaborada por Vianna, tratando-se de poética feminista, que contribui para o destaque ao papel afirmativo do feminino no mundo público. Poética feminista que utiliza a linguagem não como expressão apenas de uma individualidade, mas como desdobramento de uma discussão política de uma coletividade. A linguagem é, dessa forma, um gesto de reivindicação e de contestação política.

\section{FEMINIST POETICS AND VIOLENCE: \\ A READING OF THE SHORT STORY "WATER" BY ANA PAULA PACHECO}

IPOTESI, JUIZ DE FORA, v.23, n.1, p. 65-76, jan./jun. 2019 


\begin{abstract}
This article aims to analyze the "Water" story in Ana Paula Pacheco 's book, "The house of their own", in which the woman talks about herself, promotes questions about her social condition and denounces the violence practiced by her companion. The process of memory / invention is pointed, in this work, out as a possible methodological category of analysis. The memory, forged in the author's imagination, promotes what is seen as invention, but with a questioning, subversive, feminist gesture.
\end{abstract}

KEYWORDS: Ana Paula Pacheco. Feminist poetic. Genre. Violence.

\title{
REFERÊNCIAS
}

ABDALA JÚNIOR, Benjamin. Literatura, história e política: literaturas de língua portuguesa no século XX. 2. ed. São Paulo: Ateliê Editorial, 2007.

ARÊAS, Vilma. Posfácio. In: PACHECO, Ana Paula. A casa deles. São Paulo: Nankin, 2009. p. 89-93.

BRASIL. Decreto-Lei $n^{\circ}$. 2.848, de 7 de dezembro de 1940. Institui o Código Penal Brasileiro.

Lei $n^{\circ}$. 11.340, de 7 de agosto de 2006. Cria mecanismos para coibir a violência doméstica e familiar contra a mulher, nos termos do $\S 8^{\circ}$ do art. 226 da Constituição Federal, da Convenção sobre a Eliminação de Todas as Formas de Discriminação contra as Mulheres e da Convenção Interamericana para Prevenir, Punir e Erradicar a Violência contra a Mulher; dispõe sobre a criação dos Juizados de Violência Doméstica e Familiar contra a Mulher; altera o Código de Processo Penal, o Código Penal e a Lei de Execução Penal; e dá outras providências.

CHAUI, Marilena. Sobre a violência. Belo Horizonte: Autêntica Editora, 2017.

CHEVALIER, Jean; GHEERBRANT, Alain. Dicionário de Símbolos. Tradução Vera de Costa e Silva. 11. ed. Rio de Janeiro: José Olympio, 1997.

DUARTE, Constância Lima. "Literatura feminina e crítica literária". In: Encontro Nacional da ANPOLL, 1988, Belo Horizonte. Boletim do GT A Mulher na Literatura. Belo Horizonte: Faculdade de Letras da UFMG, 1988, p. 70-79.

FIRMINO, Flávio Henrique; PORCHAT, Patrícia. "Feminismo, identidade e gênero em Judith Butler: apontamentos a partir de "problemas de gênero"'. In: Doxa: Revista Brasileira de Psicologia e Educação, Araraquara, v. 19, n. 1, janeiro/junho 2017, p. 51-61. Disponível em: 〈https://periodicos.fclar.unesp.br/doxa/article/view/10819>. Acesso em 13/04/2019, às $15 \mathrm{~h}$.

HOHLFELDT, Antonio Carlos. Conto brasileiro contemporâneo. 2. ed. Porto Alegre: Mercado Aberto, 1988.

KAFKA, Franz. A construção. Trad. Modesto Carone. São Paulo: Brasiliense, 1994.

OLIVEIRA, Anelito de. Ana Paula Pacheco - A casa deles. In: Estudos de Literatura Brasileira Contemporânea, n. 36, 2010, p. 253-255. Disponível em:

IPOTESI, JUIZ DE FORA, v.23, n.1, p. 65-76, jan./jun. 2019 
<http://periodicos.unb.br/index.php/estudos/article/view/2899>. Acesso em 13/04/2019, às $15 \mathrm{~h} 30$.

PACHECO, Ana Paula. A casa deles. São Paulo: Nankin, 2009.

PIGLIA, RICARDO. "Teses sobre o conto". In: Formas breves. Tradução de José Marcos Mariani de Macedo. São Paulo: Companhia das Letras, 2004, p. 89-94. Disponível em: <https://iedamagri.files.wordpress.com/2014/07/piglia-teses-sobre-o-conto-e-novas.pdf >. Acesso em 13/04/2019, às 15h19.

PISCITELLI, Adriana. "Reflexões em torno do gênero e feminismo". In: Poéticas e políticas feministas. Organizado por Cláudia de Lima e Costa e Simone Pereira Schmidt. Florianópolis: Editora Mulheres, 2004, p. 43-66.

RAGO, Margareth. “Adeus ao feminismo? Feminismo e (pós)modernidade no Brasil”. In: Cadernos AEL, n. 3/4, 1995/1996, p. 12-43. Disponível em:

<https://www.ifch.unicamp.br/ojs/index.php/ael/article/view/2612/2022>. Acesso em 13/04/2019, às 15 h14.

SILVA, Acir Dias da. "Imagens de Kafka: Olhares para A construção". In: Revista Línguas \& Letras, vol. 11, n. 21, 2010. Disponível em: <e-

revista.unioeste.br/index.php/linguaseletras/article/download/4511/3465>. Acesso em $13 / 04 / 2019$, às 15 h25.

SCOTT, Joan. "Gênero, uma categoria útil de análise histórica”. Educação e Realidade, v. 20, jul. - dez., 1995.

SCHMIDT, Rita Terezinha. "Repensando a cultura, a literatura e o espaço da autoria feminina". In: Rompendo o silêncio: gênero e literatura na América Latina. Organizado por Márcia Hoppe Navarro. Porto Alegre: Editora da Universidade/UFRGS, 1995, p. 182-189.

VIANNA, Lúcia Helena. "Poética feminista - poética da memória". In: Labrys: estudos feministas, n. 4, agosto/dezembro 2003. Disponível em

<https://www.labrys.net.br/labrys4/textos/lucia1.htm>. Acesso em 13/04/2019, às 15 h15.

WOOLF, Virgínia. Um teto todo seu. Tradução Vera Ribeiro. São Paulo: Nova Fronteira, 1985. Disponível em <http://brasil.indymedia.org/media/2007/11/402799.pdf>. Acesso em $13 / 04 / 2019$, às 15 h20.

\section{Data de submissão: 18/06/2019}

Data de aceite: 04/09/2019

IPOTESI, JUIZ DE FORA, v.23, n.1, p. 65-76, jan./jun. 2019 